\title{
THE CONTENT AND METHODS OF CONDUCTING EXTRA-CURRICULAR SPORTS FOR LOWER SECONDARY SCHOOL STUDENTS IN TAY NINH PROVINCE, VIETNAM
}

\author{
Nguyen Thanh Tuan', \\ Duong Ngoc Truong', \\ Nguyen Thi Huong Thuy ${ }^{3}$, \\ Nguyen Quang Son ${ }^{4 i}$ \\ 1Tay Ninh Junior High School, \\ Vietnam \\ ${ }^{2} \mathrm{PhD}$, Sai Gon University, \\ Vietnam \\ 3Thu Dau Mot University, \\ Vietnam \\ ${ }^{4}$ Assoc. Prof., \\ University of Economics Ho Chi Minh City, \\ Vietnam
}

\begin{abstract}
:
The paper aims to provide a comprehensive, scientific and thorough description of the content and methods of how extra-curricular sports activities are conducted for lower secondary school students in Tay Ninh province. To investigate the dependable data, the research employed a range of trustworthy approaches including document synthesizing, interviewing the students and PE teachers in some lower secondary schools, and evaluating the gathered data. The results indicate that the most popular sports among the PE teachers and students are football, badminton, and volleyball which are mostly organized in group, class, and club practice, without an instructor. About the practice durations, it generally ranges from thirty minutes to two hours, equating to two or three sessions at school. Moreover, these activities usually take place in school, and it is mainly held in the afternoon or after theoretical learning.
\end{abstract}

Keywords: content, methods, extra-curricular sports activities, secondary school students, Tay Ninh

i Correspondence: sonnq@ueh.edu.vn 


\section{Introduction}

It is widely acknowledged that physical education (PE) and sports activities are indispensable components in the educational process and individuals' comprehensive development. With different educational components, PE is considered as an indirect means of advancing the productivity of each person and society as a whole. Hence, physical education has been becoming an organic part of the purposes of education and training, which is to help individuals grow mentally, physically, spiritually, and ethically. Although sometimes it is influenced by different factors of general education, it still plays a role in supporting and developing those areas of education to some level. In other ways, the interaction and harmonious blending of many parts of the educational process result in a high level of effectiveness in the education of the entire person. Therefore, we cannot overlook the significant benefits of physical education and sports activities in schools.

Despite the involvement of provincial officials, the fact shows that the practice of physical education for lower secondary school students in Tay Ninh province is hidden by several obstacles and limits. The first one is that the content of extracurricular activities seems not appealing at all when traditional ethnic sports and folk games are not integrated into the format. Not only that, the construction and training sessions have not been well-organized, resulting in not yet to fulfill students' sports training needs. As a consequence, the students are not highly motivated to enthusiastically engage in sports at school. Therefore, it is urgent to adjust the physical education's format in order to respond in time to students' growth and social expectations.

Because the content and methods play an important role in conducting extracurricular sports activities for the students, we believe that assessing and analyzing the current content and methods employed for holding physical activities is the foundation for advanced innovation. Thus, based on awareness of the importance and urgency of the aforesaid issue, I decided to proceed with my research on the topic: "The content and methods of conducting extra-curricular sports for lower secondary school students in Tay Ninh province, Vietnam".

\section{Method}

Research objectives are to present a complete, scientific, and detailed description of the content and methods being used to conduct extracurricular sports activities for lower secondary school students in Tay Ninh province. Research methodologies include document synthesis and analysis, interviews, and mathematical and statistical analysis.

The subjects of the research are:

- 2780 students from several Tay Ninh province's secondary schools;

- 32 PE teachers from several Tay Ninh province's secondary schools. 


\section{Research results}

The following results are obtained from the questionnaires and surveys of $32 \mathrm{PE}$ teachers and 2780 junior students (760 ones who frequently and 2020 ones who occasionally participate in extra-curricular sports activities) in several secondary schools in Tay Ninh province.

\subsection{About the content of extra-curricular activities}

The results of student surveys are presented in Table 1.

Table 1: The content of extra-curricular sports

activities of the secondary students in Tay Ninh province

\begin{tabular}{|c|c|c|c|c|c|c|c|c|c|c|c|c|c|}
\hline Spo & equency & & & సี & $\stackrel{\infty}{\Xi}$ & ฮี & & $\frac{\infty}{\dot{z}}$ & $\stackrel{\infty}{\Xi}$ & 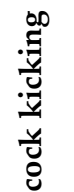 & & & \\
\hline & Male & Numk & 190 & 88 & 20 & 72 & 54 & 42 & 20 & 4 & 8 & 2 & 500 \\
\hline & & $\%$ & 38.0 & 17.6 & 4.0 & 14.4 & 10.8 & 8.4 & 4.0 & 0.8 & 1.6 & 0.4 & 100 \\
\hline $\bar{\Xi}$ & Female & Number & 38 & 64 & 6 & 70 & 28 & 24 & 24 & 6 & 0 & 0 & 260 \\
\hline$\vec{g}$ & & $\%$ & 14.6 & 24.6 & 2.3 & 26.9 & 10.8 & 9.2 & 9.2 & 2.3 & 0.0 & 0.0 & 100 \\
\hline & $\Sigma$ & Number & 228 & 152 & 26 & 142 & 82 & 66 & 44 & 10 & 8 & 2 & 760 \\
\hline & & $\%$ & 30.0 & 20.0 & 3.4 & 18.7 & 10.8 & 8.7 & 5.8 & 1.3 & 1.1 & 0.3 & 100 \\
\hline & Male & Number & 351 & 147 & 85 & 149 & 67 & 45 & 60 & 23 & 23 & 20 & 970 \\
\hline & & $\%$ & 36.2 & 15.2 & 8.8 & 15.4 & 6.9 & 4.6 & 6.2 & 2.3 & 2.3 & 2.1 & 100 \\
\hline$\Xi$ & Female & Number & 117 & 121 & 129 & 219 & 121 & 40 & 117 & 49 & 85 & 52 & 1050 \\
\hline$\overline{\tilde{g}}$ & & $\%$ & 11.1 & 11.5 & 12.3 & 20.9 & 11.5 & 3.8 & 11.1 & 4.7 & 8.1 & 5.1 & 100 \\
\hline 0 & $\Sigma$ & Number & 468 & 268 & 214 & 368 & 188 & 85 & 177 & 72 & 108 & 72 & 2020 \\
\hline & & $\%$ & 24.2 & 13.4 & 10.5 & 18 & 9.1 & 4.2 & 8.5 & 3.4 & 5.1 & 3.5 & 100 \\
\hline & Male & Number & 541 & 235 & 105 & 221 & 121 & 87 & 80 & 27 & 31 & 22 & 1470 \\
\hline & & $\%$ & 37.1 & 16.4 & 6.5 & 14.9 & 8.8 & 6.5 & 5.1 & 1.6 & 2.0 & 1.3 & 100 \\
\hline క & Female & Number & 155 & 185 & 135 & 289 & 149 & 64 & 141 & 55 & 85 & 52 & 1310 \\
\hline$\stackrel{0}{\circ}$ & & $\%$ & 12.3 & 16.2 & 8.8 & 23.0 & 11.2 & 5.8 & 10.4 & 3.8 & 5.2 & 3.3 & 100 \\
\hline & $\Sigma$ & Number & 696 & 420 & 240 & 510 & 270 & 151 & 221 & 82 & 116 & 74 & 2780 \\
\hline & & $\%$ & 26.7 & 16.3 & 7.4 & 18.3 & 9.8 & 6.2 & 7.3 & 2.5 & 3.3 & 2.1 & 100 \\
\hline
\end{tabular}

Table 1 indicates:

There are several different preferences of the secondary students in Tay Ninh province towards the different types of extra-curricular sports activities. The results from the students who frequently join in those physical activities show that they tend to practice football $(30.0 \%)$ for the highest and the least for other unpopular sports $(0.4 \%)$. Besides football, the survey has collected the figures of other popular sports including volleyball $(20 \%)$, badminton $(18.7 \%)$, athletics $(10.8 \%)$, martial arts $(8.7 \%)$, swimming (5.8\%), table tennis (3.4\%), shuttlecock kicking (1.3\%), and chess $(1.1 \%)$. Furthermore, several differences between boys' and girls' tastes are also figured out through the table. 
For boys, the highest practice is for football which accounts for $38 \%$ and the lowest is unpopular sports $(0.4 \%)$; besides, volleyball $(17.6 \%)$, badminton $(14.4 \%)$, athletics $(10.8 \%)$, martial arts $(8.4 \%)$, swimming and table tennis $(4.0 \%)$, shuttlecock kicking $(0.8 \%)$ and chess (1.6\%). For girls, badminton $(26.9 \%)$ is the highest and the lowest is for chess and other unpopular sports (0.0\%); also, volleyball (24.6\%), athletics (10.8\%), martial arts and swimming (9.2\%), table tennis and shuttlecock kicking $(2.3 \%)$. The following pie charts (Figure 1) is to present the given statistics.

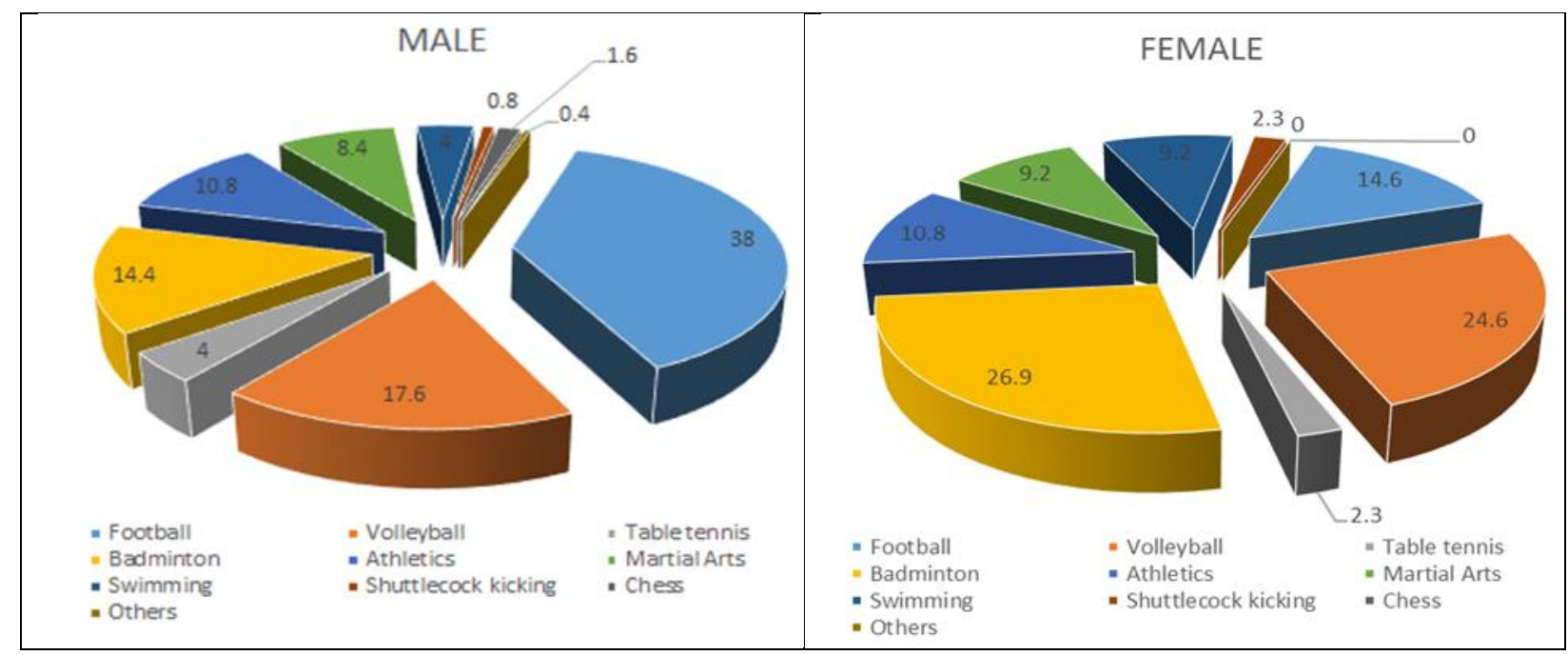

Figure 1: The content of extra-curricular sports activities of the junior secondary students in Tay Ninh province frequently participating in sports practice

Furthermore, the statistics also show that junior students who occasionally participate in extracurricular sports at Tay Ninh's secondary schools prefer to practice football the most $(24.2 \%)$ and soccer the least (3.4\%), followed by badminton $(18.0 \%)$, volleyball $(13.4 \%)$, table tennis $(10.5 \%)$, athletics $(9.1 \%)$, swimming $(8.5 \%)$, chess $(5.1 \%)$, martial arts $(4.2 \%)$, and other (3.5\%). Football is the most popular sport among boys $(36.2 \%)$, while other content is the least popular (2.1\%). Also, other sports popular among boys include badminton (15.2\%), volleyball (15.4\%), table tennis $(8.8 \%)$, athletics $(6.9 \%)$, swimming (6.2\%), martial arts $(4.6 \%)$, shuttlecock kicking $(0.8 \%)$, and chess $(2.3 \%)$. On the other side, girls prefer badminton $(20.9 \%)$ over martial arts $(3.8 \%)$, with table tennis $(12.3 \%)$, volleyball and athletics (11.5\%), football and swimming (11.1\%), chess $(8.1 \%)$, other content (5.1\%), and shuttlecock kicking (4.7\%). The following pie charts (Figure 2 ) is to present the given data. 


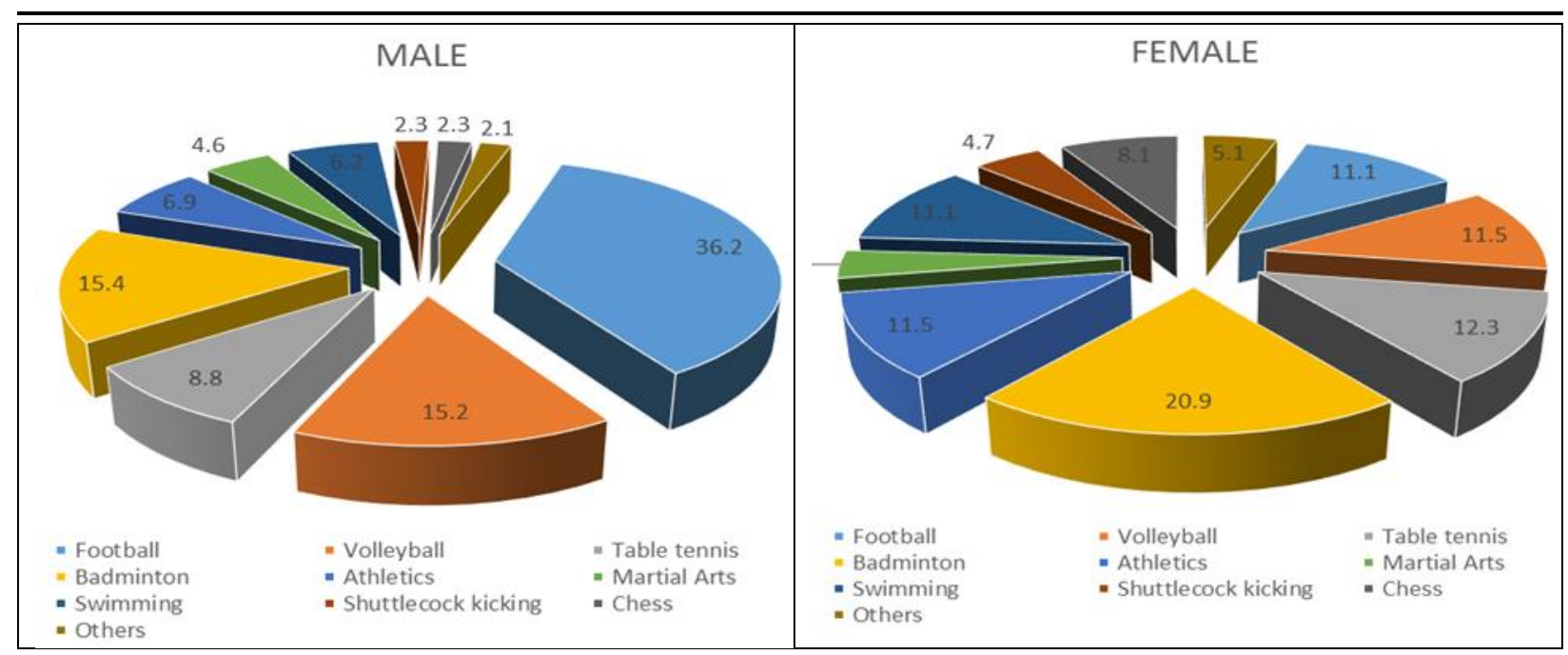

Figure 2: The content of extra-curricular sports activities of the junior secondary students in Tay Ninh province occasionally participating in sports practice

Overall, junior students at secondary schools in Tay Ninh province choose football the most $(26.7 \%)$ and other contents the least $(2.1 \%)$; following badminton $(18.3 \%)$, volleyball $(16.3 \%)$, athletics $(9.8 \%)$, table tennis $(7.4 \%)$, swimming $(7.3 \%)$, martial arts $(6.2 \%)$, chess $(3.3 \%)$, and shuttlecock kicking $(2.5 \%)$. On the one hand, for the male students, football accounts for the highest $(37.1 \%)$ while the lowest is for other content $(1.3 \%)$; other sports relating to volleyball $(16.4 \%)$, badminton $(14.9 \%)$, athletics $(8.8 \%)$, martial arts and table tennis (6.5\%), swimming (5.1\%), chess $(2.0 \%)$ and shuttlecock kicking (1.6\%). On the other hand, for the female students, they choose to practice badminton the most $(23.0 \%)$, the lowest is other content (3.3\%); the other sports activities volleyball $(16.2 \%)$, athletics $(11.2 \%)$, swimming $(10.4 \%)$, table tennis $(8.8 \%)$, martial arts $(5.8 \%)$, chess $(5.2 \%)$ and shuttlecock kicking $(3.8 \%)$. All the points shall be illustrated in Figure 3 below.

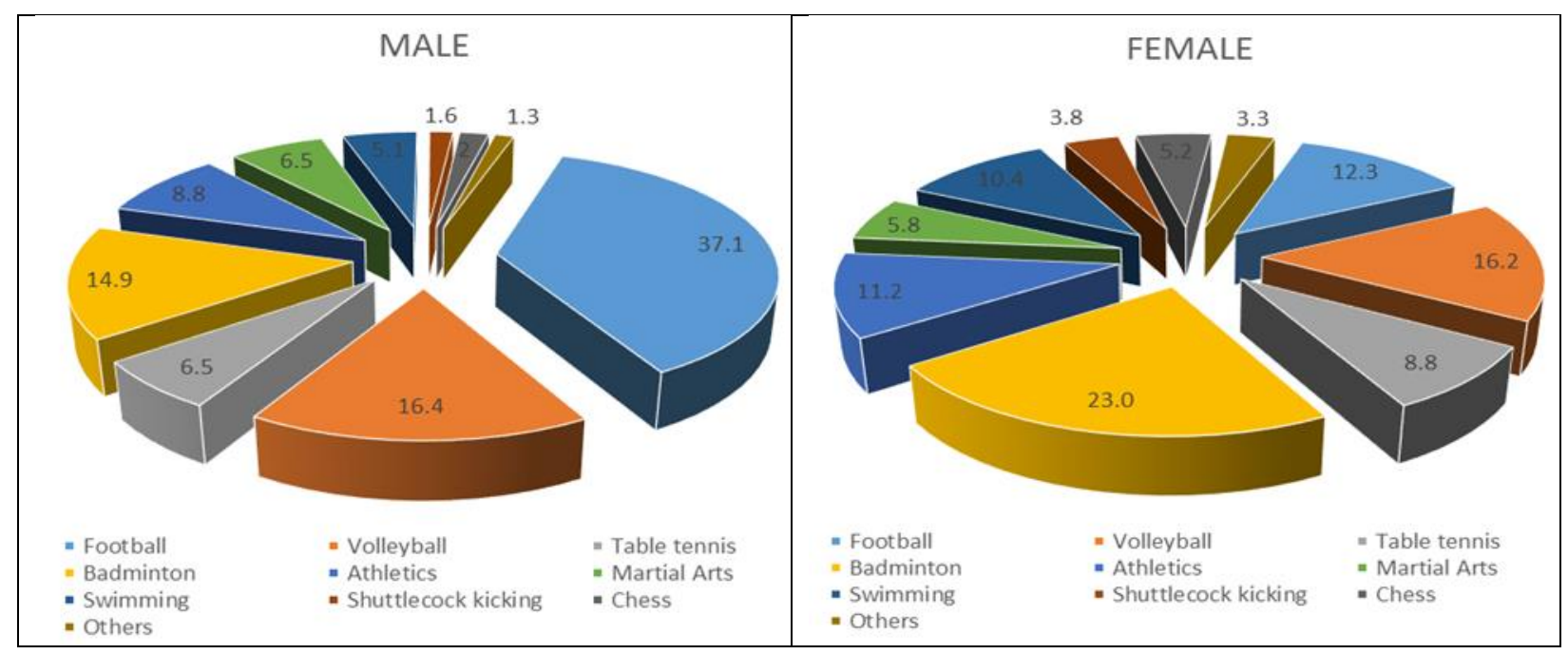

Figure 3: The content of the extracurricular sports activities participated in by the total number of junior secondary students in Tay Ninh province 
As shown in the above analysis and figures 1, 2 and 3, we have spotted a small difference in male and female junior students' preferences in extracurricular sports at secondary schools in Tay Ninh province. While football is the most favored sport among the boys and followed by badminton, volleyball, athletics, and table tennis, badminton has the largest proportion in the girls' choices and it is followed by volleyball, athletics, swimming, and table tennis.

Students who participate in extracurricular sports practice on a limited basis prefer badminton, table tennis, volleyball, athletics, and swimming to the students who attend more frequently.

Table 2 shows the results of surveys of PE teachers in Tay Ninh province's secondary schools regarding the content of extracurricular sports training and teaching.

Table 2: Results of teacher surveys on the content of extracurricular sports training and education for lower secondary school students in Tay Ninh province

\begin{tabular}{|l|l|c|c|c|c|}
\hline \multirow{2}{*}{ Order } & \multirow{2}{*}{ Content } & \multicolumn{2}{|c|}{ The first sport } & \multicolumn{2}{c|}{ The second sport } \\
\cline { 3 - 6 } & & Number & $\mathbf{\%}$ & Number & \% \\
\hline 1 & Football & 11 & 34.4 & 6 & 18.8 \\
\hline 2 & Volleyball & 7 & 21.9 & 7 & 21.9 \\
\hline 3 & Table tennis & 1 & 3.1 & 2 & 6.3 \\
\hline 4 & Badminton & 5 & 15.6 & 6 & 18.8 \\
\hline 5 & Athletics & 1 & 3.1 & 2 & 6.3 \\
\hline 6 & Martial arts & 1 & 3.1 & 2 & 6.3 \\
\hline 7 & Swimming & 2 & 6.3 & 2 & 6.3 \\
\hline 8 & Shuttlecock kicking & 1 & 3.1 & 2 & 6.3 \\
\hline 9 & Chess & 1 & 3.1 & 1 & 3.1 \\
\hline 10 & Aerobics & 2 & 6.3 & 2 & 6.3 \\
\hline Total & & 32 & 100 & 32 & 100 \\
\hline
\end{tabular}

Table 2 illustrates that football (34.4\%), volleyball (21.9\%), and badminton (15.6\%) are the first and most popular extracurricular sports with the most PE teachers in charge at secondary schools in Tay Ninh province. Swimming, aerobics, shuttlecock kicking, chess, athletics, martial arts, and table tennis are the remaining physical activities with fewer instructors. Similar to the first sports, volleyball (21.9\%), badminton and football (18.8\%) are also the most popular activities for the second extracurricular sports. The other subjects have a low proportion of teachers regarding swimming, aerobics, shuttlecock kicking, athletics, martial arts, table tennis and chess. Figures 4 aims to compare the quantity of each extracurricular sports content taught by PE teachers at secondary schools of Tay Ninh province. 


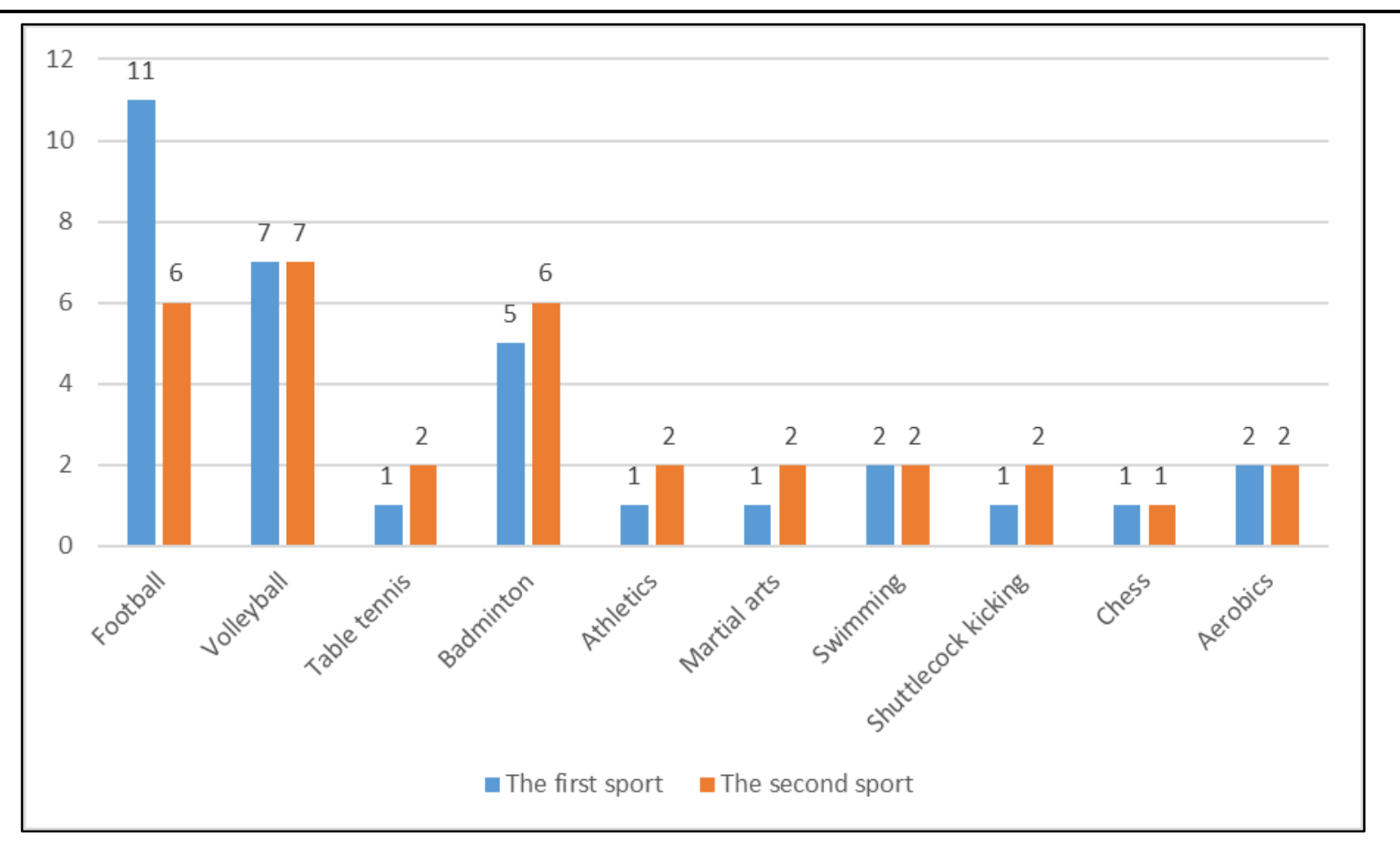

Figure 4: Comparison of the quantity of each extracurricular sports content taught by PE teachers at secondary schools of Tay Ninh province

According to the results of the preceding assessment, we can easily find out that whereas football, volleyball, and badminton attract a lot of attention, there has very little interest in athletics, basketball, table tennis, martial arts, shuttlecock kicking, swimming, aerobics and chess. Consequently, it can be seen from the fact that the contents of the Tay Ninh Phu Dong Health Association's competition program have not been properly taught, which is one of the primary reasons why Tay Ninh's secondary schools should quickly upgrade the content of extracurricular sports for the students.

\subsection{About the methods of conducting extra-curricular sports}

Table 3 presents the results obtained from the surveys on the ways of how the extracurricular sports are held by the junior students at Tay Ninh secondary school students.

Table 3: The methods employed by junior students to hold extra-curricular sports at secondary schools in Tay Ninh province $(n=760)$

\begin{tabular}{|c|c|c|c|c|}
\hline Order & Findings & & Number & Ratio (\%) \\
\hline \multirow[t]{5}{*}{1} & \multirow{5}{*}{$\begin{array}{l}\text { Forms of } \\
\text { practices }\end{array}$} & School teams & 117 & 15.4 \\
\hline & & Groups, classes & 256 & 33.7 \\
\hline & & Clubs & 199 & 26.2 \\
\hline & & Self-practice & 188 & 24.7 \\
\hline & & Total & 760 & 100.0 \\
\hline \multirow[t]{3}{*}{2} & \multirow{3}{*}{$\begin{array}{l}\text { Methods of } \\
\text { conducting } \\
\text { practices }\end{array}$} & With an instructor & 227 & 29.9 \\
\hline & & Without an instructor & 443 & 58.3 \\
\hline & & Both & 90 & 11.8 \\
\hline
\end{tabular}


Nguyen Thanh Tuan, Duong Ngoc Truong, Nguyen Thi Huong Thuy, Nguyen Quang Son

THE CONTENT AND METHODS OF CONDUCTING EXTRA-CURRICULAR SPORTS

FOR LOWER SECONDARY SCHOOL STUDENTS IN TAY NINH PROVINCE, VIETNAM

\begin{tabular}{|c|c|c|c|c|}
\hline & & \begin{tabular}{|l|} 
Total \\
\end{tabular} & 760 & 100.0 \\
\hline \multirow[t]{5}{*}{3} & \multirow[t]{5}{*}{ Duration } & Below 30 minutes & 70 & 9.2 \\
\hline & & 30 minutes -01 hour & 230 & 30.2 \\
\hline & & 01 hour -02 hours & 350 & 46.1 \\
\hline & & Above 02 hours & 110 & 14.5 \\
\hline & & Total & 760 & 100.0 \\
\hline \multirow[t]{5}{*}{4} & \multirow{5}{*}{$\begin{array}{l}\text { The number of } \\
\text { training sessions } \\
\text { per week }\end{array}$} & 01 sessions & 170 & 22.4 \\
\hline & & 02 sessions & 298 & 39.1 \\
\hline & & 03 sessions & 170 & 22.4 \\
\hline & & Above 03 sessions & 122 & 16.1 \\
\hline & & Total & 760 & 100.0 \\
\hline \multirow[t]{5}{*}{5} & \multirow[t]{5}{*}{ Time } & Morning & 208 & 27.4 \\
\hline & & Noon & 58 & 7.6 \\
\hline & & Afternoon (after school) & 344 & 45.3 \\
\hline & & Leisure time & 150 & 19.7 \\
\hline & & Total & 760 & 100.0 \\
\hline \multirow[t]{4}{*}{6} & \multirow[t]{4}{*}{ Location } & At school & 457 & 60.1 \\
\hline & & At home & 135 & 17.8 \\
\hline & & Other & 168 & 22.1 \\
\hline & & Total & 760 & 100.0 \\
\hline \multirow[t]{5}{*}{7} & \multirow[t]{5}{*}{ Expenses } & Below 50,000 VND & 210 & 27.6 \\
\hline & & From 50,000VND - 100,000VND & 202 & 26.6 \\
\hline & & From $100,000 \mathrm{VND}-200,000 \mathrm{VND}$ & 282 & 37.1 \\
\hline & & Above 200,000VND & 66 & 8.7 \\
\hline & & Total & 760 & 100.0 \\
\hline
\end{tabular}

Table 3 represents that:

- Forms of practices: The most common way is to hold in groups or classes $(33.7 \%)$, followed by the club training and self-practice accounting for $26.2 \%$ and $24.7 \%$ respectively, whereas the lowest proportion is for school teams (15.4\%).

- Methods of conducting practices: Surprisingly, the number of junior secondary students declaring that there is no instructor during their extra-curricular sports $(58.3 \%)$ is considerably higher than those who have at least one teacher $(29.9 \%)$ and both $(11.8 \%)$.

- Duration: From one to two hours for practicing sports is the most selected item $(46.1 \%)$, while the least is under 30 minutes (9.2\%); besides, $30.2 \%$ of junior secondary students tend to spend from 30 minutes to 01 hour and merely $14.5 \%$ for above 2 hours. The statistics shall be presented in Figure 5.

- The number of training sessions per week: The majority of students at Tay Ninh's secondary school participate in extra-curricular sports during two sessions (39.1\%) whereas spending one session and three sessions for them is not much popular $(22.4 \%)$. As expected, only $16.1 \%$ of Tay Ninh secondary students are involved in more than three sessions for those extra physical activities (16.1\%). 


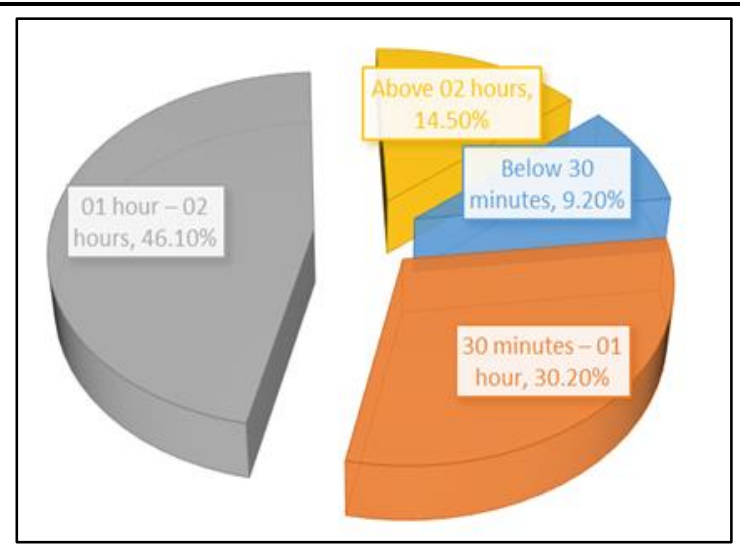

Figure 5: Ratio of durations for practicing extra-curricular sports of lower secondary school students in Tay Ninh province

- Time: Afternoon (after school) is the most common time for Tay Ninh's lower secondary pupils to practice, representing $45.6 \%$, while midday is the least popular (7.6\%). Moreover, doing in the morning and in their leisure time account for $27.4 \%$ and $19.7 \%$, respectively. Figure 6 is employed to express the above data.

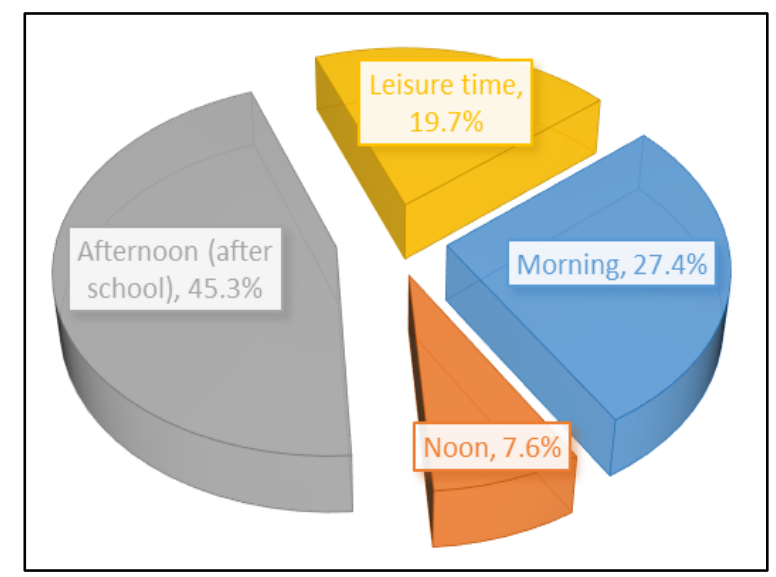

Figure 6: Ratio of time points practicing extra-curricular sports of lower secondary school students in Tay Ninh province

- Location: Lower secondary students in Tay Ninh province tend to practice the most in school, accounting for $60.1 \%$, and the least at home, accounting for $17.8 \%$, with the remaining $22.1 \%$ practicing elsewhere.

- Expenses: 100,000 to 200,000 VND is the amount of money that the majority of Tay Ninh secondary students spend on extra-curricular sports (37.1\%) while 200,000 VND takes the least choices in terms of their budget for extra-curricular sports (8.7\%); the remaining proportion is less than $50,000 \mathrm{VND}$, accounting for $27.6 \%$, and from $50,000 \mathrm{VND}$ to $100,000 \mathrm{VND}$, accounting for $26.6 \%$. Figure 7 is to illustrate the points. 


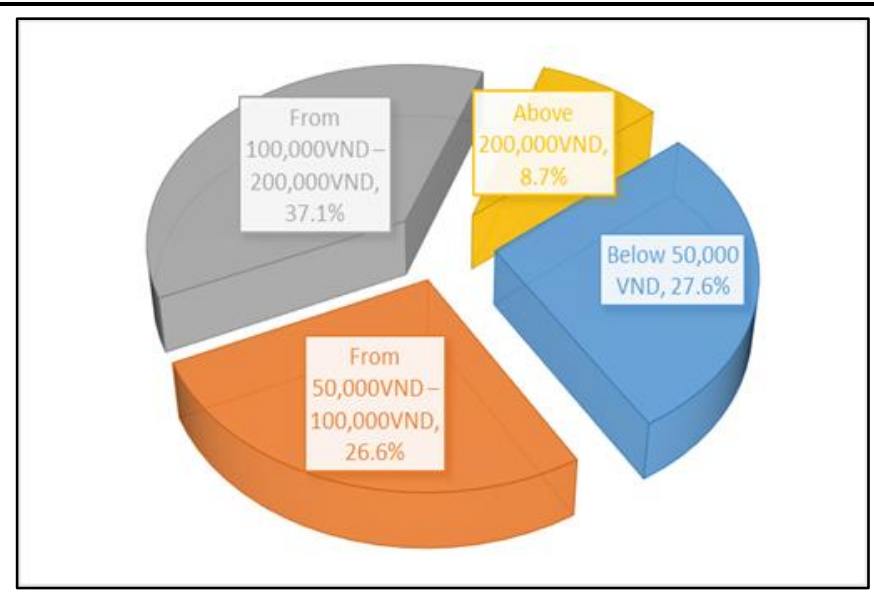

Figure 7: Ratio of expenses on extra-curricular sports of lower secondary school students in Tay Ninh province

Overall, these are the outstanding points in the methods of conducting extracurricular sports retrieving from the analysis of the table 3 and three figures 5, 6 and 7 . Tay Ninh lower secondary students tend to practice in groups, classes and clubs (59.9\%), without an instructor (58.3\%), from 30 minutes to 02 hours $(76.3 \%)$ which are equivalent 2 or 3 sessions $(61.5 \%)$, mostly at school (60.1\%) and do in the afternoon (after school) or in the morning (72.7\%), usually spend from 50,000 VND to 200,000 VND on such those activities $(63.7 \%)$.

Table 4 presents the results obtained from the surveys on the ways of how the extracurricular sports are held by the junior students at Tay Ninh secondary school students.

Table 4: The methods employed by PE Teachers to hold extra-curricular sports at secondary schools in Tay Ninh province $(n=32)$

\begin{tabular}{|c|c|c|c|c|}
\hline Order & Findings & & Number & Ratio (\%) \\
\hline \multirow[t]{5}{*}{1} & \multirow{5}{*}{$\begin{array}{l}\text { Forms of } \\
\text { teaching }\end{array}$} & School teams & 20 & 62.5 \\
\hline & & Groups, classes & 11 & 34.4 \\
\hline & & Clubs & 01 & 3.1 \\
\hline & & Private training & 00 & 0.0 \\
\hline & & Total & 32 & 100.0 \\
\hline \multirow[t]{5}{*}{2} & \multirow[t]{5}{*}{ Duration } & Below 01 hour & 01 & 3.1 \\
\hline & & 01 hour -02 hours & 25 & 78.1 \\
\hline & & 02 hours -03 hours & 06 & 18.8 \\
\hline & & Above 03 hours & 00 & 0.0 \\
\hline & & Total & 32 & 100.0 \\
\hline \multirow[t]{4}{*}{3} & \multirow{4}{*}{$\begin{array}{l}\text { The number of } \\
\text { training sessions } \\
\text { per week }\end{array}$} & 02 sessions & 20 & 62.5 \\
\hline & & 03 sessions & 11 & 34.4 \\
\hline & & Above 03 sessions & 1 & 3.1 \\
\hline & & Total & 32 & 100.0 \\
\hline \multirow[t]{3}{*}{4} & \multirow[t]{3}{*}{ Time } & Morning & 08 & 25.0 \\
\hline & & Noon & 01 & 3.1 \\
\hline & & Afternoon & 23 & 71.9 \\
\hline
\end{tabular}


Nguyen Thanh Tuan, Duong Ngoc Truong, Nguyen Thi Huong Thuy, Nguyen Quang Son

THE CONTENT AND METHODS OF CONDUCTING EXTRA-CURRICULAR SPORTS

FOR LOWER SECONDARY SCHOOL STUDENTS IN TAY NINH PROVINCE, VIETNAM

\begin{tabular}{|l|l|l|c|c|}
\hline \hline & Total & 32 & 100.0 \\
\hline \multirow{5}{*}{5} & Income & Below 0.5 million VND & 01 & 3.1 \\
\cline { 3 - 4 } & From 0.5 million VND to 1 million VND & 16 & 50.0 \\
\cline { 3 - 4 } & From 1 million VND to 1.5 million VND & 13 & 40.6 \\
\cline { 3 - 4 } & Above 1.5 million VND & 02 & 6.3 \\
\cline { 3 - 5 } & Total & 32 & 100.0 \\
\hline
\end{tabular}

Table 4 represents that:

- Forms of teaching: The form used most regularly by PE teachers at Tay Ninh secondary schools is to train for school teams (62.5\%), followed by for club training $(34.4 \%)$ and groups or classes $(3.1 \%)$, while the least popular form is to train privately (0\%).

- Duration: From 1 to 2 hours for training sports is the most selected item by the teachers $(78.1 \%)$, while holding it in over 3 hours receives zero selection $(0.0 \%)$; besides, $18.8 \%$ PE teachers at Tay Ninh secondary schools tend to spend from 02 hours to 03 hours and merely $3.1 \%$ for below 1 hour.

- The number of training sessions per week: The teaching and training of extracurricular sports by PE teachers at Tay Ninh secondary schools mostly takes up 2 sessions $(62.5 \%)$ and very rarely takes up over 3 lessons (3.1\%), yet 3 sessions accounting for $34.4 \%$.

- Time: Afternoon is the most popular time for Tay Ninh's secondary teachers holding some physical activities for their students, representing $71.9 \%$, while midday is the least popular (3.1\%). Moreover, holding in the morning account for $27.4 \%$.

- Income: The most popular income for PE teachers at Tay Ninh secondary schools is from 0.5 million VND to 1 million VND (50.0\%) and the least popular one is below 500,000 VND (3.1\%); whereas, from 1 million VND to 1.5 million VND accounts for $40 \%$, and above 1.5 million VND humbly accounts for $6.3 \%$.

According to the results of the above analysis, the current status of teachers and coaches' extracurricular sports teaching and training is primarily team and club training (96.9\%), training from 1 to 3 hours (96.9\%), practicing 02 - 03 sessions per week (96.9\%), working in the afternoon or after school (71.9\%), and the income is between 500,000 and $1,500,000$ VND (90.6\%).

\section{Conclusion}

The male students at Tay Ninh secondary schools like practicing football the most, followed by badminton, volleyball, athletics and table tennis; whereas the female students tend to choose badminton as the best, followed by volleyball, athletics, swimming and table tennis. Moreover, the students who occasionally participate in extracurricular sports practice are likely to choose badminton, table tennis, volleyball, athletics and swimming more than the students who attend frequently. 
The secondary school students in Tay Ninh province mainly practice extracurricular sports in groups, classes, and clubs (59.9\%), without instructors (58.3\%), practice from 30 minutes to 2 hours $(76.3 \%)$ and from 2 to 3 sessions $(61.5 \%)$. Furthermore, they mostly exercise at school $(60.1 \%)$ and in the afternoon (after school) as well as in the morning $(72.7 \%)$. Their budgets spent for such activities commonly are between 50,000 and 200,000 VND (63.7\%).

The content of physical teaching and training at Tay Ninh secondary schools mainly focuses on football, volleyball, and badminton.

The teachers and coaches in there mostly hold extracurricular sports in the form of school teams and clubs (96.9\%), training from 01 to 03 hours $(96.9 \%)$, and working about 2 or 3 sessions per week (96.9\%), practicing in the afternoon or after-school (71.9\%), and the income from 500,000 to 1,500,000 VND (90.6\%).

\section{Conflict of Interest Statement}

The authors declare no conflicts of interests.

\section{About the Authors}

Nguyen Thanh Tuan has been a P.E teacher at a lower secondary school in Tay Ninh province, Vietnam. At the same time, he is attending $\mathrm{PhD}$ program at Ho Chi Minh University of Physical Education and Sports, Vietnam.

Duong Ngoc Truong has held his PhD degree and has been working at Sai Gon University, Vietnam.

Nguyen Thi Huong Thuy has held his PhD degree and has been working at Thu Dau Mot University, Vietnam.

Nguyen Quang Son has held his PhD degree and has been working at University of Economics Ho Chi Minh City, Vietnam.

\section{References}

[1]. Ministry of Education and Training (2008), Decision No. 72/2008 / QD-BGDDT dated December 23, 2008. Promulgating regulations on organizing extra-curricular sports activities for students.

[2]. Ministry of Culture, Sports and Tourism (2019), Circular No. 01/2019 / TT-BVHTTDL, January 17, 2019, Regulations on assessing mass physical and sports training.

[3]. Tran Kim Cuong (2008). The reality of extracurricular sports practice in Ninh Binh provincial schools, Journal of Sports Science (6), Institute of Sports Sciences, Hanoi, p.56- 60 .

[4]. Tran Huu Hung (2015). Research on the improvement of forms and content of physical training and sports for junior high school students in Gia Lai - Kon Tum Highland), Doctoral Thesis in Education, Institute of Sports Science. 
[5]. Le Van Lam - Pham Xuan Thanh (2008). School sports curriculum. Sports Book Publishing House, Hanoi.

[6]. National Assembly of the Socialist Republic of Vietnam (2018). Amending and supplement to the Sports Law. Law No. 26/2018 / QH14, dated 14/6/2018.

[7]. Prime Minister (2015), Decree No. 11/2015 / ND-CP, January 31, 2015, Regulations on education and sports activities in the school.

[8]. Hoang Trong, Chu Nguyen Mong Ngoc (2008). Analyzing research data with SPSS), Hong Duc Publishing House.

Creative Commons licensing terms

Authors will retain the copyright of their published articles agreeing that a Creative Commons Attribution 4.0 International License (CC BY 4.0) terms will be applied to their work. Under the terms of this license, no permission is required from the author(s) or publisher for members of the community to copy, distribute, transmit or adapt the article content, providing a proper, prominent and unambiguous attribution to the authors in a manner that makes clear that the materials are being reused under permission of a Creative Commons License. Views, opinions and conclusions expressed in this research article are views, opinions and conclusions of the author(s). Open Access Publishing Group and European Journal of Physical Education and Sport Science shall not be responsible or answerable for any loss, damage or liability caused in relation to/arising out of conflict of interests, copyright violations and inappropriate or inaccurate use of any kind content related or integrated on the research work. All the published works are meeting the Open Access Publishing requirements and can be freely accessed, shared, modified, distributed and used in educational, commercial and non-commercial purposes under a Creative Commons attribution 4.0 International License (CC BY 4.0). 